\title{
The “Grave Risk Exception”, EFficiency and the Hague Convention on Child Abduction: a LaW AND ECONOMICS APPROACH
}

\author{
Natalia Camba Martins* \\ Gustavo Ferreira Ribeiro **
}

\begin{abstract}
1 Introduction. 2 The rules vs. standards debate. 3 The Hague convention on child abduction. 3.1 The negotiation process and the rules and standards struggle. 3.1.1 Drafting Efforts. 3.1.2 Delegations' Comments. 3.1.3 Preliminary Remarks of the Negotiation Process and the Rules and Standards Debate. 3.2 The code of conduct: a standard-like solution? 4 Conclusions. References.
\end{abstract}

\begin{abstract}
Contracting States adopted the Hague Convention on Child Abduction in 1980 after an extensive negotiation effort. The final text added exceptions to the primary objective of prompt return of children wrongfully abducted to a country different from the one he/she habitually resided. Among them, the grave risk exception deals with situations in which the child, upon its return, may face physical or psychological harm or otherwise be placed in an intolerable situation. We posit in this paper that the elaboration and the evolution of this exception have been efficient-prone in terms of legal design. To support our claim, the paper draws on the methodology of law and economics, more specifically on the standard and rules debate. The research demonstrates that the representatives of States faced heightened costs of specifications and low frequency of cases, which suggested the adoption of a standard. Moreover, nowadays, enduring specification costs (which prompt for standards) and the elaboration of a Guide of Good Practices related to the concerned exception appear to be the best alternative available to advance its implementation. Therefore, on both its origin and evolvement, the exception follows an efficient framework in terms of legal design.
\end{abstract}

Keywords: International Child Abduction. Hague Convention. Grave Risk Exception. Law and Economics. Rules and Standards.

* Doutoranda do Programa de Doutorado em Direito do UniCEUB. Mestre em Direito das Relações Internacionais (UniCEUB). Bacharela em Direito (USP). Advogada da União. E-mail: <natycmartins@hotmail. com >. https://orcid.org/0000-0001-9869-7499

** Professor do Programa de Mestrado e Doutorado em Direito do UniCEUB. Doutor em Direito (SJD, Indiana University Bloomington). Mestre em Direito (UFSC). Bacharel em Direito e Ciência da Computação (UFMG). Advogado. E-mail: <Gustavo.Ribeiro@ceub.edu.br>. https://orcid.org/0000-0001-9452-9981 


\section{INTRODUCTION}

It has been repeatedly said that the Hague Convention on the Civil Aspects of Child Abduction $^{1}$ is primarily an instrument of International Private Law that aims at preventing the international removal of children. ${ }^{2}$ Moreover, it intends to promptly return children wrongfully transferred to or retained in any Contracting State in order to restore the status quo ante $^{3}$ (BEAUMONT; McELEAVY, 1999, p. 28-35; PÉREZ-VERA, 1982, p. 435; WEINER, 2000, p. 597-598).

However, negotiators mitigated this straightforward message - prevention and return of the child - during its drafting. The treaty included situations where the return of the child to its country of habitual residence can be denied. Among its exceptions, the grave risk exception is a recurrent one, according to which:

Article 13. [...] the judicial or administrative authority of the requested State is not bound to order the return of the child if the person, institution or other body that opposes its return establishes that $[\ldots]$ b) there is a grave risk that his or her return would expose the child to physical or psychological harm or otherwise place the child in an intolerable situation (HAGUECONFERENCE ON PRIVATE INTERNATIONAL LAW, 1982, p. 416).

The broad language of the provision (grave risk, physical harm, psychological harm and intolerable situation) suggests, at first glance, a high degree of discretion regarding the interpretation of the Hague Convention. It also reflects a possible balance towards a feasible treaty at the time of negotiation.

In this paper, we posit that the law and economics ( $L \& E$ ) rules and standards debate can enlighten the above discussion in an area barely perceived as economic-oriented. While law and economics has been construed and consolidated under domestic law issues, especially in the US, it has entered international law much more recently (see DUNOFF; TRACHTMAN, 1999, p. 49-55) and even less in private international law (MICHAELS, 2008; O'HARA; RIBSTEIN, 1999; RUHL, 2006).

The argument is three-folded: (i) high specification costs and the low frequency of cases, by the time of negotiation, recommended the emergence of the grave risk exception as a standard, rather than a rule; (ii) though frequency of new cases has been on the raise, specification costs of Article 13(1)b remain exceptionally high; and (iii) finally, and consequentially, the efficient design of legal norms supports the idea that alignments towards efficiency design occurred with the Hague Convention origin and evolution. For the purposes of this article, we consider the grave risk exception as a single provision, although we do not ignore that "the combination of a rule and its exceptions may be little different in practical terms from a standard." (POSNER, 2007, p. 588).

In this sense, the first part of this article summarizes the rules and standards debate. The second part applies the theoretical framework to the treaty's negotiation process. It intends to describe the overall costs of the agreement in terms of specification, compliance, and 
adjudication costs, as well as the frequency of cases. Subsequently, we observe the increase of cases along 30 years after the adoption of the Hague Convention and that countries have engaged on the elaboration of a Guide of Good Practices on the Interpretation and Application of the grave risk exception. ${ }^{4}$ The Guide would be evidence that specification costs remain a burden to an amendment and reflect an efficiency-oriented outcome.

\section{THE RULES VS. STANDARDS DEBATE}

This section introduces the dichotomy between rules and standards. It focuses on the main elements likely to enlighten the analysis of the Hague Convention and its grave risk exception.

As a starting point, the rules and standards categories in L\&E resemble the rules and principles classes in doctrinal (dogmatic) theory. In this sense, the dichotomy between rules and standards concerns the degree of precision and clearness of legal norms. Rules rest in the edge of more precise, detailed and specific norms. Standards repose in the opposite direction.

Whereas doctrinal analysis deals with categories, subtypes, and hermeneutics of rules and standards, L\&E methodology adds economic considerations about the design of efficient norms. It explores, for instance, specification costs, adjudication costs, and compliance costs in the life cycle of legal norms. Building and referring to each other, the literature covers, among others, domestic production of norms (KAPLOW, 1992, 1999; EHLRICH; POSNER, 1974; SUNSTEIN, 1995), conflicts of laws (BAIRD; WEISBERG, 1982; DIVER, 1983; KENNEDY, 1976; O'HARA; RIBSTEIN, 1999; RUHL, 2006; SCHÄFER, 2002) and international law (GUZMAN, 2008; TRACHTMAN, 2013).

Specification costs refer to the costs associated with drafting, negotiating, assembling, deliberating, and discussing the norm. An important variable in this stage is the information available and the technical capacity of whom specifies the norm. Generally, as rules are by definition more detailed, they incur in more specification costs than standards. This stage is primarily associated with legislative branch but also secondary norm production related to administrative agencies.

Adjudication costs denote costs associated with litigation. At large, more precise legal provisions such as rules lead to speedier judicial processes and reduce informational costs for future disputes. On the other hand, standards demand more interpretation, thus costs, than rules as, by definition, their meaning needs fulfilling. Standards also shift more discretionary power to Courts, as a result of incremented space to interpret. Naturally, the judicial branch and judges have a large role in the cost component of this stage.

Finally, compliance costs represent costs associated with adjustment of general behavior. Rules provide less costly adjustments for people, in general, as they can be easily communicated. The vagueness of standards would result in more costly adjustments compared to rules by ordinary people, since the meaning of the standard is not clearly available.

A recurrent illustration of these ideas' application alludes to automobile traffic norms (POSNER, 2007, p. 586; RUHL, 2006, p. 832; SCHÄFER, 2002, p. 1; SUNSTEIN, 1995, p. 
965). Whereas "driving carefully" embodies a standard, the " $x$ ' miles speed limit" represents a rule. In theory, the concerned standard would demand less effort for rule makers to agree upon. Simply put, one would hardly disagree about the need to drive carefully. That means lower specification costs, as compared to the concerned rule. However, as driving imposes risks and accidents might occur, courts would need to interpret, in each case, whether the driver made his/her way with the proper attention (higher adjudication costs). Besides, people would also have more difficulty ex ante to determine the level of driving precaution whilst facing the standard: what level of carefulness do they need as ordinary people? (higher compliance costs).

At the end, a balance between the three types of the acknowledged costs would be central to the efficient design of legal commands. The following table summarizes the general framework:

Table 1 - General framework for rules and standards

\begin{tabular}{l|l|l|l}
\hline \multicolumn{1}{c|}{ Costs } & Rules & \multicolumn{1}{c|}{ Standards } & \multicolumn{1}{c}{ Unit of Analysis } \\
\hline Specification & Higher & Lower & Legislator, Administrative Authorities, Bureaucracy \\
\hline Adjudication & Lower & Higher & Courts, Judges \\
\hline Compliance & Lower & Higher & People \\
\hline \multicolumn{2}{l}{ Source: authors' elaboration }
\end{tabular}

The level of information and the intertwined dynamic of the cost categories have prompted further reserves about the suggested simplicity of the model. For instance, information availability in the specification stage, and the capacity to analyze it can, upfront, decrease the initial specification costs of rules. Moreover, considering the stages of specification and adjudication in tandem, Kaplow (1992, p. 562-563) posited that the frequency of the application of the provision is crucial in the choice between rules and standards. A predictable high number of cases makes rules preferred over standards.

On the other hand, "when frequency is low, standards tend to be preferable", since it would be a waste of energy to incur on costs in every type of contingencies that will rarely emerge. Moreover, in the compliance phase, the advantages of rules will certainly depend on "whatever individuals choose to acquire legal advice on before they act." (KAPLOW, 1992, p. 564). In other words, whenever the cost of learning the content of the legal command is high, and the cost of acquiring of legal expertise is low, people would tend to conform regardless of its form.

Sunstein, while discussing sources of law, the rule of law, and democratic issues complemented the L\&E rules and standards debate. Importantly, the author calls the attention that the category distinction depends on the understanding of whom interprets the provision: "Interpretive practices can convert an apparently rule-like provision into something very unrule-like.” (SUSTEIN, 1995, p. 959-960). He also distinguishes categories along the 
continuum of legal norms. Far from a Manichean view of rules versus standards, Sunstein (1995, p. 959-960) identifies a spectrum of norms, such as rules with excuses, presumptions, guidelines, principles, among others.

Besides, quoting Kaplow as an inspiration for his formulation, Sunstein (1995, p. 961) understands rules as an effort "to make most or nearly all judgments under the governing legal provision in advance of actual case [ex ante]" rather than ex post. And again, a continuous interpretation practice can make ex post assignments very predictable. Finally, Sunstein (1995, p. 961) also defends some level of casuistry, or case-by-case analysis, as a key factor on democratic foundations of law. The point is that the sum of insufficient information to design, ignorance about facts, values, and future developments, just to illustrate, would demand casuistry as a way to supersede abstract formulations.

From what we recollected so far, at least 3 types of costs emerge under the choice between rules and standards: (i) specification; (ii) adjudication; and (iii) compliance. The level of available information, the technical capacity to handle it, and the frequency of the application of provisions may inform choices, if one considers design efficiency. It is also hard to determine in advance the nature of the legal command, because the legal culture of each society involved in its interpretation may turn a rule-like norm into a standard and vice versa. Thus, casuistry can play an important role in the dynamics of the norms, whether one takes into account legitimacy issues.

That being said, one should yet consider that the framework has to be adjusted to the international arena. The relative costs between rules and standards - as in the domestic realm - may be acceptable as an initial framework. But in a horizontal society of states, costs are attached to different actors:

Table 2 - International Arena

\begin{tabular}{l|l|l|l}
\hline \multicolumn{1}{c|}{ Costs } & \multicolumn{1}{c|}{ Rules } & \multicolumn{1}{c}{ Standards } & \multicolumn{1}{c}{ Actors } \\
\hline Specification & Higher & Lower & Treaty negotiators \\
\hline Adjudication & Lower & Higher & International Courts \\
\hline Compliance & Lower & Higher & States; States' Branches \\
\hline Source: authors' elaboration.
\end{tabular}

Source: authors' elaboration.

Accordingly, specification costs vary in accordance with the number of potential Contracting Parties, especially when different legal cultures, objectives, and interests may conflict, which is not rare. Some authors are even skeptical that "genuine multinational collective action problems can be solved by a treaty, especially when a large number of States is involved." (GOLDSMITH; POSNER, 2005, p. 86). Similar skepticism can be found, accordingly to these authors, in Downs and Rocke (1995). In their view, 
[...] these regimes have an implicit two-step logic: in step 1, States come together and negotiate common terms [specification costs]; in step 2, States cooperate (or not) in pairs [compliance/adjudication costs], with each State in a pair complying with the common terms as long as the other State in the pair does too (GOLDSMITH; POSNER, 2005, p. 87).

Moreover, "when the common terms - the treaty terms - do not maximize the value as between the States in a pair, they may agree upon alternative terms that do; but, often, renegotiation is too costly and the common terms are used instead." (GOLDSMITH; POSNER, 2005, p. 87).

An immediate presumption is that international treaties involving many countries are harder to be specified (higher specification costs). Moreover, authors (DUNOFF; TRACHTMAN, 1999, p. 35; TRACHTMAN, 2013, p. 240-244) highlight that it is not difficult to see standards as a way, ex ante, to minimize cost of contracting. Unsurprisingly, this is much of the same idea developed under domestic law, whilst under relevant uncertainty in international law, "by specifying general standards, and delegating to dispute settlement bodies the responsibility to apply these standards [adjudication costs], States are able to include complex state contingency in their contracts with significantly less variable contracting costs." (TRACHTMAN, 2013, p. 201).

As to information, depending on the development and institutional capacity of the countries, bureaucracy included, they may face difficulties in obtaining and processing it. Not for less, Guzman (2008, p. 134-136), drawing from international relations literature, points out that Contracting Parties sometimes prefer less binding agreements. Soft law, treaties with escape clauses, and standards appear as a choice for States that value flexibility under information asymmetry. However, although the overall costs of a treaty can be higher at the international scenario, States are said to prefer treaties over non-binding arrangements especially because: "(1) treaties usually require legislative consent, a process that conveys important information about state preferences for the treaty; (2) treaties implicate certain interpretative default rules; or (3) treaties convey a more serious commitment than nonlegal agreements do." (GOLDSMITH; POSNER, 2005, p. 91).

The application of the above included frameworks to the Hague Convention leads us to some surprising scenarios. First, regarding the costs of adjudication and compliance, although the Hague Convention is said to be an instrument of Private International Law - a treaty - it contains a hybrid mix of obligations regarding its subjects. While some legal commands are directed to States and their branches (e.g., the obligation of prompt return of internationally abducted children to their State of habitual residence), the overall message of the treaty has individuals (private parties) as its direct target. ${ }^{7}$ If the State fails with the obligation of prompt return, the State may - at least theoretically - face an International Court; if a parent unilaterally abducts a child to another country, he/she may face a domestic lawsuit at the State of Refugee.

This seems also to be the case of the "grave risk exception": it is a provision that has, simultaneously, at least 2 targets: the (judicial) authority in charge of adjudicating a specific case 
(of international child abduction), and the public (in general and specific parents or intended abductors). The message to the judicial authority (adjudication) states that when dealing with an abduction case, the (default) return of the child may be denied if the "grave risk exception" is adequately established (in conformity with the domestic rules on the burden of proof of that State). But the provision also provides a message to individuals (compliance): there are situations where the unilateral removal of a child from the State of habitual residence may be legitimate.

Secondly, and with respect to the costs of specification, the Hague Convention also has multiple subjects. During the treaty's negotiation phase, we find the treaty negotiators, delegates from each State that is taking part at the specification exercise. Once the treaty is finalized, the domestic legislators, the Administrative Authorities and the bureaucracy enter the scenario, to put their efforts on a new negotiating/specification exercise, related to the ratification of the treaty ${ }^{8}$ and, as it is the case of some States, the domestic negotiation of an implementing legislation of the Hague Convention, at the domestic level. ${ }^{9}$

In conclusion, we posit that the structure of the Hague Convention, considered as a whole, shows a mix of Tables 1 and 2, above, where:

Table 3 - The Hague Convention

\begin{tabular}{l|l|l|l}
\hline Costs & Rules & Standards & Unit of Analysis \\
\hline Specification & Higher & Lower & $\begin{array}{l}\text { Treaty Negotiators, Legislators, Administrative Authorities, } \\
\text { Bureaucracy }\end{array}$ \\
\hline Adjudication & Lower & Higher & Courts, Judges (domestic and international) \\
\hline Compliance & Lower & Higher & People, States and State`s Branches \\
\hline \multicolumn{2}{l}{ Source: authors' elaboration. }
\end{tabular}

As we suggest along this paper, the grave risk exception emerged as a standard among Contracting Parties. We are not in a position to affirm that the negotiators, at that time, consciously decided to adopt a standard, instead of a rule, to save overall costs. But we propose that efficiency underlines the economic rationale of Article 13.b, considering the factors discussed above. Moreover, the succeeding enforcement - or difficulties in enforcement - of Article 13.b allows us to support our hypothesis of an efficient framework. After the introduction of the theoretical framework, we now proceed in more detail, with the analysis of the Hague Convention and its relationship with efficient legal design.

\section{THE HAGUE CONVENTION ON CHILD ABDUCTION}

\subsection{THE NEGOTIATION PROCESS AND THE RULES AND STANDARDS STRUGGLE}

\subsubsection{Drafting Efforts}

The Hague Conference on International Private Law (hereinafter called Hague Conference or $\mathrm{HCCH}$ ) is a global inter-governmental organization, composed of 83 
member States (82 States and the European Union), to develop and service "multilateral legal instruments, which respond to global needs", by the "adoption of special rules known as 'private international law' rules". (HAGUE CONFERENCE ON PRIVATE INTERNATIONAL LAW, 2017).

The statutory mission of the Conference is to work for the progressive unification of these rules. This involves finding internationally-agreed approaches to issues such as jurisdiction of the courts, applicable law, and the recognition and enforcement of judgments in a wide range of areas, from commercial law and banking law to international civil procedure and from child protection to matters of marriage and personal status (HAGUE CONFERENCE ON PRIVATE INTERNATIONAL LAW, 2017, online).

Only almost two decades after the United Nations Declaration of the Rights of the Child (1959), the Hague Conference included the subject "legal kidnapping" in its agenda in 1976. It is mentioned that:

During the 1970s, a committee of experts at the Council of Europe began the preparation of an European convention to ensure enforcement of custody orders across transnational borders, culminating in the European Convention on Recognition and Enforcement of Decisions concerning Custody of Children and on Restoration of Custody of Children in 1980. During the same period, a group of experts at the Hague Conference [of International Private Law] also decided to put the problem of 'legal kidnapping' on the agenda for future work (SILBERMAN, 2006, p. 301).

The 1961 Hague Protection of Minors Convention - subsequently revised as the 1996 Hague Convention on Protection of Children- was in effect since 1969, "but it offered little prospect of reducing wrongful removals and retentions." (SILBERMAN, 2006, p. 301).

The analysis of previous efforts to reach the agreement help to illustrate the rules and standards methodology adopted in this essay. As a cornerstone of the negotiations, in the Fall of 1978, Ms. Adair Dyer, First Secretary of the Permanent Bureau of the Hague Conference, sent a questionnaire to all Member States, accompanied by an elaborated sociological study and report about international child abduction. ${ }^{10}$

Governments analyzed the Dyer Report in August 1978, after countries' reactions to the referred questionnaire. It was recalled, firstly, that the Thirteenth Session of the Conference, in 1976,

Warmly supported the Recommendation that the Conference undertake this topic, which has become intercontinental in its scope with a pattern of abduction routes cross-hatched across the globe, from Australia to Austria, from Canada to France (and back, through the secondary abduction), from Berlin to Israel, England to Holland, Holland to Morocco and so on in a seemingly endless flow (HAGUE CONFERENCE ON PRIVATE INTERNATIONAL LAW, 1982, p. 12).

The Dyer Report stressed the difficulties in defining the problem, as well as finding suitable terminology for it. It also mentioned the work performed by a Committee of 
Experts, under the auspices of the Council of Europe, in the European context (HAGUE CONFERENCE ON PRIVATE INTERNATIONAL LAW, 1982, p. 14). ${ }^{11}$ The report mitigated worries about overlapping work, "because of the worldwide scope of the problem, since abductions by air on an intercontinental basis are becoming more frequent". It also mentioned that the work of the Hague Conference should not interfere with the work performed at the Council of Europe, "but the Conference can gain some insight in a few avenues which possibly might be followed from the work of the Committee of Experts on the Custody of Children of the Council of Europe." (HAGUE CONFERENCE ON PRIVATE INTERNATIONAL LAW, 1982, p. 15). ${ }^{12}$

The interaction between the Council of Europe and the Hague Conference, which was translated to the rule and standards debate, served to reduce specification costs on the elaboration of the legal provisions of the Hague Convention. Most countries engaged at the negotiation stage of the Hague Convention were also Member States to the Council of Europe. ${ }^{13}$

On the other hand, negotiators had poor statistics available on the number of abductions of children by their parents not only around the globe, but also within the countries engaged on the negotiation exercise. The sense was that "a rapid increase in such occurrences has come about within recent years" especially due to "improved transport facilities and unimpeded crossing of borders." (HAGUE CONFERENCE ON PRIVATE INTERNATIONAL LAW, 1982, p. 18-19).

A questionnaire very similar to the one sent to countries by the Secretary General of the Hague Conference was also transmitted by the International Social Service (ISS) to its branches. The ISS is "an international federation of interconnected NGOs and partners that works towards re-establishing links within a family separated by borders." (THE INTERNATIONAL SOCIAL SERVICE, 2016, online). In total, ISS regional branches reported 99 different cases occurred from 1974-1979, involving only 11 countries: Australia, France, Germany, United Kingdom, Greece, Italy, Japan, the Netherlands, Switzerland, United States of America and Venezuela. The study recognized that "one should bear in mind that the data given does not constitute a representative sample of all the occurring child abductions by a parent. The findings of this Report are based on a limited number of cases in which the International Social Service was involved." (HAGUE CONFERENCE ON PRIVATE INTERNATIONAL LAW, 1982, p. 132).

Those circumstances, we believe, increased the specification costs, because of the difficulty of regulating a conduct to which information seemed to encompass only a partial fragment of the phenomena.

As the negotiations advanced, the difficulties in reaching consensus became evident. A key question concerned the recognition and enforcement of foreign custody judgment. After several debates and a study prepared by the Secretariat of the Conference, negotiators reached a compromise. The draft rejected "any attempt to lay down rules of recognition and 
enforcement of foreign custody decisions." (BODENHEIMER, 1980, p. 102). Then, a less ambitious formula, calling only for prompt restoration of the custody situation that existed prior to the abduction, loomed. This is another example found on the records of the Hague Convention to illustrate the specification difficulties - and, on the law and economics jargon, the specification costs - involved on its negotiation, and its effects on the final outcome.

The specification of the grave risk exception also faced difficulties. Once the return of the child to the country of its habitual residence was, and continues to be, the raison d'être of the treaty, exceptions to this straightforward message had to be adequately constructed, without underscoring the object and purpose of the treaty.

The Explanatory Report of the Hague Convention mentioned that each of the words about the grave risk exception were carefully chosen, in order to achieve a "fragile compromise" (PÉREZ-VERA, 1982, p. 461), at that point, among 25 drafting countries. ${ }^{14}$

The Dyer Report suggested that its scope was not to decide on the rigorousness and the manner of application of the legal norms necessary for protecting the stability of children, since

It should be noted here that some feedback from professionals in the field of international social work suggests the possibility that not all 'kidnappings' are bad for the child, that in some cases of deteriorating situations or ambivalent feelings on the part of the parent having custody or possession of the child the abduction may have a positive effect on the child, precisely by removing it from an unstable or uncertain environment. Whether these kidnappings may be viewed as being analogous to a husband's desertion of his wife, 'the poor man's divorce', or whether it simply relieves the custodial parent from having to admit publicly his/her inability to cope and the fact that the child will be better off, at least temporarily, with the other parent, the ultimate effects on the child's stability in some cases may be positive (HAGUE CONFERENCE ON PRIVATE INTERNATIONAL LAW, 1982, p. 22).

The "interests of the child" - another term used by the convention - are considered vague and "more closely to a sociological paradigm than a concrete juridical standard" (PEREZ-VERA, 1982, p. 431). The Dyer Report points out that the Council of Europe found similar patterns of standards in the field of conflict of laws. It reminds the "elusive modern concept which has gained some headway in recent years as an approach to the solution of conflict-of-laws questions: the reference to the law having the 'most significant relationship' or the "closest connection." (HAGUE CONFERENCE ON PRIVATE INTERNATIONAL LAW, 1982, p. 22). This is another example of the vague nature of the language adopted by the Conference, indicating that the use of standards on the construction of the legal provision had an important role.

The Dyer Report also considered that, when dealing with treaty terms, "unless a legislative effort is made to set out the specific elements for establishing these standards in particular cases, one ultimately falls back on more nebulous methods of fleshing out the bones, such as 'choice-influencing considerations' or 'principles of preference." (HAGUE CONFERENCE ON PRIVATE INTERNATIONAL LAW, 1982, p. 23). We consider the 
rapporteur's remarks of "legislative exercise" and "nebulous methods" as an exteriorization of high specification costs at the moment and the likely outcome of a standard.

Another alternative would be to postpone the fulfilling of the standard content on caseby-case for adjudicators. That would represent an increase on the costs of adjudication (and compliance), but could be an efficient alternative, when specification costs at negotiation are burdensome. Indeed, negotiators had in mind the creation of an international court to adjudicate transnational child abduction cases. However, the idea was considered "more unwieldy in the context of the Hague Conference than [it was] within the regional framework of the Council of Europe, for the obvious reason that the worldwide scope of the [Hague] Conference involves greater differences and more diverse cultural patterns." (HAGUE CONFERENCE ON PRIVATE INTERNATIONAL LAW, 1982, p. 47). The Dyer Report admitted that "the global village is not with us quite yet and one hesitates to predict results which would inspire confidence emanating from 'ad hoc' courts accepting members from widely scattered parts of the globe" (HAGUE CONFERENCE ON PRIVATE INTERNATIONAL LAW, 1982, p. 47).

In March 1979, the "Special Commission on International Child Abduction by One Parent" 15 met to discuss the text of the convention. ${ }^{16}$ According to Shapira $(1989$, p. 190192), the Special Commission advised that the targeted convention "might contain rules forbidding or limiting the exercise of judicial jurisdiction to determine child custody on the merits in a contracting State to which the child had been brought following an abduction", and considered that "such prohibition or limitation is indeed a necessary corollary to the obligation of the latter State's authorities to return promptly an abducted child to its country of habitual residence”. Regarding the equivalent of Article 13(1)b, the Special Commission indicated that "the prompt return of an abducted child could only be declined [...] if such return was likely to be gravely prejudicial to the interests of the child." (SHAPIRA, 1989, p. 191).

In November 1979, the Special Commission adopted the preliminary draft Convention. The draft encompassed the grave risk exception, as such:

[...] the judicial or administrative authority of the requested State is not bound to order the return of the child if the person who has removed or retained the child establishes that $[\ldots]$ b) there is a substantial risk that the return would expose to child to physical and psychological harm or otherwise place the child in an intolerable situation (HAGUE CONFERENCE ON PRIVATE INTERNATIONAL LAW, 1982, p. 168).

The Special Commission Report posited that, at that time, negotiators knew that the terms substantial risk, psychological harm and intolerable situation were vague enough to allow interpretation discretion in "entirely different ways" (HAGUE CONFERENCE ON PRIVATE INTERNATIONAL LAW, 1982, p. 203). The discussions during the Special Commission, accordingly to Ms. Pérez-Vera, recorded the attempts to reduce flexibility: 
The substantial risk designates a serious risk which may be objectively verified, but it does not comprise the idea of 'immediate' risk; this latter interpretation was discarded in the end. As to the psychological harm, the Special Commission intended it to cover both the mental harm and a certain aspect of the moral harm, but it has knowingly avoided the latter expression, which is too vague and which could even be interpreted as encompassing religious convictions. With regards to what must be understood by an intolerable situation, the special Commission had in mind an objective case; a proposal to replace the word 'intolerable' by 'unacceptable' was rejected because this latter word comprises an element of subjective evaluation which had to be avoided. Moreover, the Special Commission thought that the exception would not apply if the child's return was thought to be prejudicial to its economic or educational future (HAGUE CONFERENCE ON PRIVATE INTERNATIONAL LAW, 1982, p. 203).

The discussion sounds like a play on words. Whilst trying to enlighten, to some extent, the content of the provision, negotiators could only agree to vague expressions. The changes of expressions considered less vague - for example, between intolerable and unacceptable - kept the imprecision and the difficulties for ordinary people to comply, ex ante, its exact content. This scenario, we believe, while potentially reducing the specification costs, would actually maintain the costs of adjudication and compliance substantially high.

Less than one year after that, the Fourteenth Quadrennial Session of the Hague Conference (Fourteenth Session) ${ }^{17}$ "entrusted the task of preparing the [final version] Convention to its First Commission" 18 , which was performed and completed during that Fourteenth Session, from 6 to 25 October 1980, in the course of thirteen sessions, in which "the First Commission [composed of 24 representatives] analyzed the Preliminary Draft drawn up by the Special Commission." (PÉREZ-VERA, 1982, p. 426). Representatives of 24 States worked in the preparation of this document (BODENHEIMER, 1980, p. 99). ${ }^{19}$ The draft stated that it "seeks to protect children from the harmful effects of abduction and retention across international boundaries by providing a procedure to bring about their prompt return." (HAGUE CONFERENCE ON PRIVATE INTERNATIONAL LAW, 2016, online).

In parallel to the work of the First Commission, a Drafting Committee was also nominated (PÉREZ-VERA, 1982, p. 426) and held seven meetings. The Drafting Committee worked under the chairmanship of Mr. Leal (also Vice President of the Special Commission) and included representatives from Finland, France, United Kingdom and the Reporter, Mr. Dyer, among which "several secretaries provided the Committee with extremely valuable assistance." (PÉREZ-VERA, 1982, p. 427).

Accordingly to Shapira (1989, p. 192), all 23 member countries of the Hague Conference and 16 nations with observer status ${ }^{20}$ presented at the Fourteenth Session unanimously agreed with the final text. At the end, 23 States $^{21}$ adopted the Hague Convention on October 24th, 1980 (PÉREZ-VERA, 1982, p. 426).

As mentioned, while drafting, negotiators believed ${ }^{22}$ that "child abductions, mostly by divorced or divorcing parents, had become a worldwide problem." (BODENHEIMER, 1980, 
p. 100). The increasing number of children removed from their place of habitual residence, unilaterally by one of his/her parents, was a concerning point, though global data about the number of abductions was not available. Whether the breakup of such transnational families occurs, "one of the partners may take the child to his or her country of origin [or to a third State], or may retain the child in that country after a visit." (BODENHEIMER, 1980, p. 100).

The most comprehensive documental source to understand the negotiating procedures of the Hague Convention is the Actes et document de la Quatorzième session, au 6 au 25 Octobre 1980 - Tome III Enlèvement d'enfants edited by the General Secretary of the Hague Conference on Private International Law, and printed by the Imprimerie National of the Hague, in 1982, hereinafter mentioned as Actes et documents of the Hague Conference (HAGUE CONFERENCE ON PRIVATE INTERNATIONAL LAW, 1982, p. 1-482).

This document contains a) a questionnaire on international child abduction by one parent; b) a Report on the same subject drawn up by Mr. Adair Dyer (the Dyer Report, see note below); c) the replies of the governments; d) the conclusion on the discussion held by the Special Commission of March 1979; e) the preliminary draft Convention prepared by the Special Commission of November 1979; f) the Explanatory Report of Miss Elisa Pérez-Vera (PÉREZ-VERA, 1982); g) the comments of the governments on this preliminary draft; h) minutes and working documents of the First Commission, which dealt with this subject at the Fourteenth Session; i) minutes of the final session which approved the draft convention; j) the text of the Convention as it was adopted.

It is mentioned that the Explanatory Report "is not limited to supplementing the Special Commission's Report, but rather constitutes an autonomous commentary on the Convention." (HAGUE CONFERENCE ON PRIVATE INTERNATIONAL LAW, 1982, p. 5). Other documents were also included, as a Summary of the findings on a Questionnaire studied by International Social Service (preliminary Document no. 3 of February 1979), Observations by the Secretariat of the Council of Europe relating to the Questionnaire prepared by the Permanent Bureau of the Hague Conference on private international, including a draft European convention on recognition and enforcement of decision concerning custody and on restoration of custody of children (Preliminary Document no 4 of march 1979).

The drafters under the First Commission's sessions also invited countries to discuss the proposal. The next section analyzes the oral interventions of Germany, Austria, Belgium, Canada, United States and United Kingdom, and relate them to the analysis framework.

\subsubsection{Delegations' Comments}

As to the delegations' comments, this section reveals similar pattern of costs as before. For instance, the delegation of Germany suggested a narrow wording for the grave risk provision, "with more objective criteria" that could "restrict the danger of a too large scope of discretion", such as: "an itemization of the general wording, breaking it down to individual concrete dangerous situations, such as neglect, maltreatment, abuse, etc. This 
way, the competent courts would be compelled more precisely to consider and state the reasons for their decision." (HAGUE CONFERENCE ON PRIVATE INTERNATIONAL LAW, 1982, p. 217).

Although the German government did not use the expression cost - and no costlike wording exists along the text -, we can relate the comment with concerns of higher adjudication and compliance costs of vague provisions.

The Austrian remarks referred to delay perils (adjudication costs), stating that the provision "includes the risk that the prompt return of the child - as it is one of the objects of the Preliminary Draft (Article 1, paragraph a) - might be thwarted or at least delayed." (HAGUE CONFERENCE ON PRIVATE INTERNATIONAL LAW, 1982, p. 219) It also mentions that for that risk, the Council of Europe rejected the grave risk exception as a ground for denying the return of the abducted child. The Austrian government, while not offering any alternative wording for the provision, hoped that "none or only very little use will be made of the possibility" (HAGUE CONFERENCE ON PRIVATE INTERNATIONAL LAW, 1982, p. 219).

With criticism, Belgium's comments suggested an amendment to the provision to clarify that (only) the judicial authorities of the country of habitual residence of the child are in a position to determine whether there is a grave risk for the child. We understand that this comment intended to limit the power of judicial authorities, which would reduce adjudications costs; specially by reducing the scope of analysis of the authorities of the country where the child was removed to. It was mentioned that

« de l'avis des autorités belges, le projet de Convention devrait être sérieusement amendé. [...] on peut envisage un aménagement de l'article 12 et plus particulièrement de l'article $12 \mathrm{~b}$. Il est certain que cette disposition, qui peut se comprendre à première vue, va être utilisée par le ravisseur pour s'opposer ou retarder le retour de l'enfant. [...] si la lettre b devait être rédigée de telle sorte que le retour de l'enfant ne sera pas ordoné si le ravisseur établit que selon les autorités judiciaires du pays d'où l'enfant a été enlevé, il y a un risque grave pour ce dernier » (HAGUE CONFERENCE ON PRIVATE INTERNATIONAL LAW, 1982, p. 220).

Canada, in turn, recognized that the grave risk exception was the "main ground of defense". Trying to clarify its content, the Canadian representatives illustrated that physical harm could encompass physical violence, beating or maltreatment; psychological harm could mean mental cruelty; intolerable situation, although considered "somewhat vague", was also "undoubtedly justified", as aimed to protect the child, nor the abductor". Representatives also emphasized adjudication costs due to vagueness of standards and discretion of judges:

The commission did not adopt certain proposals aimed either at restricting the scope of the provision even further, for example through the use of the term 'immediate risk', or at broadening it, for example, in the case where the child has become integrated into its new social environment. Neither is there any mention of 'moral danger' (incest or drug addiction, for example), even though this might, in certain cases, form part of the 'intolerable situations' re- 
ferred to in the provision. Finally, a proposal that the expression 'unacceptable situation' is used instead of 'intolerable situation' was rejected ${ }^{23}$ on the ground that it allowed the judge too much discretion (HAGUE CONFERENCE ON PRIVATE INTERNATIONAL LAW, 1982, p. 234).

The United States' delegates were also very critical about the provision. They ascertained that if it were kept as such, it could endanger the objectives of the Hague Convention. They considered the exception excessively broad. The subtle difference between intolerable and unacceptable was considered of minor importance. An important point of the United States was the need to disregard educational or economic disadvantages under this exception, which emerged later in the oral discussions (HAGUE CONFERENCE ON PRIVATE INTERNATIONAL LAW, 1982, p. 242-243).

The United Kingdom delegation commented that the effectiveness of any convention on the international abduction of children will depend very largely upon the number of States that ratify it and upon the courts of those States giving it a fair effect. As other States ${ }^{24}$ it abstained from presenting specific comments on the grave risk exception.

This scenario does not seem to have changed much during the Fourteenth Session of the Hague Conference. The records of the oral discussions show that the major concerns of the Contracting Parties related to the unclear wording of the grave risk exception; especially the difficulties to reduce the high level of vagueness and the broad discretionary powers allowed to the judiciary authorities. In terms of cost language, these concerns correspond to high adjudication and compliance costs.

Therefore, States carried on the discussion on the grave risk exception elements. Belgium gave up on the substitution of the wording "physical or psychological harm" for "grave harm". Negotiators from many parties, including Israel and Greece, regarded the United States proposal, which excluded "economic or educational disadvantages" as grounds for the refusal of the return of the child, too narrow. The United Kingdom delegation suggested the inclusion of "or otherwise place the child in an intolerable situation", which was incorporated latter into the adopted text. The justification came from the situation "where one spouse was subject to threats and violence at the hands of the other and forced to flee the matrimonial home, it could be argued that the child suffered no physical or psychological harm although it was clearly exposed to an intolerable situation." (HAGUE CONFERENCE ON PRIVATE INTERNATIONAL LAW, 1982, p. 302). The adopted text of the Hague Convention did not include any specific text related to domestic violence. It seems that this comment was, at that time, an isolated concern of the UK delegation. The discussions on domestic violence and its impacts on transnational child adductions were resumed only some years after the treaty entered into force.

The United States presented a narrower formulation of the allowable exceptions at Working Document 12, "which sought to make the provisions of Article 12(1) $\mathrm{b}^{25}$ as clear and as narrow as possible, so as to deter abductions." This working document contained the following proposal, regarding Article 12(1)b: 
Amend sub-paragraph $1 \mathrm{~b}$ to read: there is a substantial risk, supported by the evidence which is supplied by the Central Authority of the State of origin or other competent authorities or persons of that State, that the return would subject the child to severe neglect conditions, maltreatment, or abuse, other than economic or educational disadvantages (HAGUE CONFERENCE ON PRIVATE INTERNATIONAL LAW, 1982, p. 263).

They also mentioned that this was an attempt to discourage the courts to engage on the merits of a custody dispute while deciding on the transnational abduction (HAGUE CONFERENCE ON PRIVATE INTERNATIONAL LAW, 1982, p. 301-302). These records show how intermingled, on our opinion, the discussions on adjudication, compliance and specification costs might be - although the States' delegates have not used this language or approach, at least not directly. Specification costs appear on the first level, followed closely by adjudication costs concerns - at least at the discussions on the vagueness of the grave risk exception. At this stage, negotiators seemed to have left compliance costs and frequency issues - raised by doctrine - to a lower level of importance.

Further, the Chairman pointed out that the objective was "to draft a Convention which could be signed by as many States as possible. The present formulation in Article 12(1)b was in the nature of a compromise". "[...] He urged delegates to direct their attention to considering provisions which would be acceptable to most States" (HAGUE CONFERENCE ON PRIVATE INTERNATIONAL LAW, 1982, p. 302). The Chairman's mediation pointed out to the probable formulation of a standard and matches Posner's observation (2007, p. 586) that the reduction on the agreement costs can be achieved by agreeing on less, leaving future resolution of the judicial authorities and compliance on the subjectivity of the individuals.

At voting, negotiators rejected the proposal contained in the Working Document no. 12 (by 12 against, 10 in favor, with 4 abstentions). The rejected text proposed an alteration of Article 12(1)b and the deletion of the words supported by the evidence that is supplied by the Central Authority of the State of origin or other competent authority or persons of that State, and the wording or abuse. Pérez-Vera (1982, p. 33) mentions that those rejections should not create the idea that the exceptions could receive a wide interpretation - the rejected proposals should not mean that more circumstances would be included as legitimate reasons for denying the return of internationally abducted children to their State of habitual residence.

The Drafting Commission worked in parallel to the delegation's meetings, as mentioned. It tried to adjust the text. On 22 October 1980, The Commission distributed a new draft of the Hague Convention (Working Document no. 75). Article 13 encompassed the grave risk exception with the following wording:

[...] the judicial or administrative authority of the requested State is not bound to order the return of the child if the person, institution or other body that opposes its return established that: [...] b) there is a substantial risk that the return would expose the child to physical and psychological harm or otherwise place the child in an intolerable situation (HAGUE CONFERENCE ON PRIVATE INTERNATIONAL LAW, 1982, p. 349-350). 
Thus, it was only at the very end of the negotiation that the efforts changed the word substantial for grave, after a brief discussion in which most of the negotiators seemed to have understood that the latter wording was stronger than the former. One can see the discussion as a last attempt to reduce the vagueness of the terms contained on the grave risk provision that would reduce overall costs. In practical term, we see both provisions as equally vague.

\subsubsection{Preliminary Remarks of the Negotiation Process and the Rules and Standards Debate}

Our first point is that the grave risk provision efficiently arose as a standard - especially for the impossibility (due to higher costs) of an ex ante definition of its terms. Thus, its content depended on ex post assignments: the judicial authority would have to decide whether the risk on the return of the child is grave, physically or psychologically, or it will, otherwise, put the child in an intolerable situation. The potential abductors would not know, ex ante and precisely, whether his/her behavior will be considered by courts and/or administrative authorities as a legitimated conduct.

From the document analysis, we could identify the attempt between negotiators to make at the end, as a member of the United Kingdom delegation referred to, a more saleable treaty. ${ }^{26}$ Negotiators tried to compromise on the provisions that were, supposedly, easily acceptable by the highest number of countries. This happened by eventually reducing the efforts to find more objective criteria for the grave risk exception.

Although the negotiators may seem to have taken into consideration the specification and, to some extent, the adjudication costs, the analysis has shown that delegations almost ignore compliance costs (although, at the practical operation of the Hague Convention they play a major role). The frequency of the grave risk exception seemed, to the negotiators, also low at the time of the drafting of the agreement. At least since 1999, some researches have been demonstrating that the nature of international child abductions has changed dramatically: ${ }^{27}$ at the time of negotiations, the highest number of abductions was perpetrated by fathers who were not entitled with custodial rights regarding the child (HAGUE CONFERENCE ON PRIVATE INTERNATIONAL LAW, 1982, p. 130-144).

More than that, the reasons for the abduction seemed to be, in the past, not the existence of a grave risk of physical or psychological harm, or an intolerable situation, but the opposition of this father against a decision of custody of the child in favor of the mother. Nowadays it has been discussed that most of the abductions are perpetrated by mothers, returning to their countries of origin, even when they are the custodial parent of the child. The number of allegations regarding the grave risk exception has increased dramatically. Although the new scenario of international child abduction may change the conclusions about the efficiency of the grave risk exception as a standard, the limits of this essay do not allow us to engage on this analysis.

As mentioned, we believe that neither adjudication nor compliance costs were adequately calculated (or even considered) by the drafters of the grave risk exception. 
Without precise information on the nature (and numbers) of the transnational child abductions, the theoretical framework related to the specification costs of the provision recommended the use of a standard. Due to the high costs of negotiating the exception and the objective of selling the treaty to the highest number of countries as possible, specification costs have been considered more relevant, leaving the compliance and the adjudication costs on a lower level of importance.

The next section discusses that the adoption of a code of conduct among parties is yet a result of elevated specification costs associated with a rule-like form, but provides an alternative efficient design on the implementation of the grave risk exception.

\subsection{THE CODE OF CONDUCT: A STANDARD-LIKE SOLUTION?}

Our analysis indicates an efficient-prone design of the Hague Convention's grave risk exception, during the negotiations of the treaty. The higher costs of negotiation related to the specification of a rule and the low frequency of cases supports our thesis. This section enhances the analysis while considering the aftermath of the Convention.

After its adoption, the Hague Convention continued under scrutiny by the ContractingStates, during the so-called sessions of the Special Commission on the Operation of the Hague Convention of 25 October 1980 on the Civil Aspects of International Child Abduction (Special Commission).

At least in three of the Special Commission meetings (1989, 1993 and 2012), the grave risk exception was under examination. At the 1989 Special Commission, Contracting Parties resumed the concerns that abductors could use the allegations of grave risk to procrastinate the return of the child. Therefore, judicial (or administrative authorities) should strictly apply the provision. The Special Commission also noted that the frequency of the allegation of the grave risk exception increased as compared to the allegation of lack of actual exercise of custodial rights (HAGUE CONFERENCE ON INTERNATIONAL PRIVATE LAW, 1989, paragraphs 26 and 28).

Thus, nine years after the agreement entered into force, there were indicatives of the importance of reducing vagueness, in order to avoid increased adjudication costs. Compliance costs might also have shown to be higher than imagined, as the frequency of the exception increased. At that Session, however, Contracting-States could not reach consensus on the definition of intolerable situation, showing again troubling specification costs.

In the 1993 Special Commission, a careful and exceptional application of the grave risk exception was still of greater concern among stakeholders (HAGUE CONFERENCE ON PRIVATE INTERNATIONAL LAW, 1993, paragraph 23). In an attempt to reduce judicial discretionary powers, the Second Special Commission stated that the grave risk exception should not be used to avoid the return of a young abducted child when she/he has not had more contact with the left parent. Another attempt is related to the hypothesis of domestic violence and sexual abuse perpetrated by one of the child's parents. The Commission posited 
that only the judicial authorities of the country of habitual residence of the child could analyze those circumstances. Negotiators could not reach a consensus on any of those matters.

The grave risk exception was the center of the debates again at the Special Commission meetings of 2011-2012. After three decades, the Commission eventually suggested the elaboration of a study aiming at the standardisation of the exception interpretation (HAGUE CONFERENCE ON PRIVATE INTERNATIONAL LAW, 2012a, paragraph 81).

The endless imprecision of the terms contained at the text of the grave risk exception, as well as the increased costs of compliance and adjudication of a standard, in our view, may be the motive - consciously or unconsciously - for so much subsequent consideration about the design of the provision. However, although the new perception could suggest that the grave risk exception should be more adequately rephrased as a rule, specification costs have been still blocking a rule-like outcome.

The international agreement counts nowadays with more than the triple of the original Contracting Parties, with even more different cultural and economic backgrounds. ${ }^{28}$ Moreover, the 2012 Special Commission's report mentions that:

The majority of experts considered that any future work should not be limited to allegations of domestic and family violence within the context of Article 13(1) b), but should include all situations of 'grave risk of harm', such as mental illness, criminal behavior or drug and alcohol abuse. Several experts explained that limiting the examination of Article 13(1) b) to domestic violence could lead to a different standard being applied to cases where domestic violence is alleged (HAGUE CONFERENCE ON PRIVATE INTERNATIONAL LAW, 2012a, p. 15).

In 2011, the Hague Conference circulated a document compiling the consideration of some State-Parties to the desirability and feasibility of an Additional Protocol to the Hague Convention and its possible content (HAGUE CONFERENCE ON PRIVATE INTERNATIONAL LAW, 2011a). Although this report has shown a certain amount of support in favor of the reduction of vagueness of some provisions of the Hague Convention including the grave risk exception- in December 2011, a follow-up document was published by the Hague Conference (HAGUE CONFERENCE ON PRIVATE INTERNATIONAL LAW, 2011b) mentioning that the focus of the 2012 Special Meeting has changed and the discussion on an Additional Protocol has been removed from the agenda.

It has been said that the scenario for this change is that it had become clear, after new consultations with the State-Parties, not to be possible to reach consensus on the scope of the work of elaborating the text for a new Protocol to the Hague Convention at that point in time (SCHUZ, 2014, p. 39-40). At this point, we posit that, among other considerations, the specification costs of a new binding international treaty were considered so high by the State-Parties - or at least to some of them - that even the discussions on a possible new treaty were removed from the agenda of the meeting. 
This Special Commission, then, concluded and recommended that

80. The Special Commission notes that the evaluation of the evidence and the determination of the grave risk of harm exception (Art. 13(1) b)), including allegations of domestic violence, are an exclusive matter for the authority competent to decide on the return, having due regard to the aim of the 1980 Convention to secure the prompt and safe return of the child.

81. The Special Commission recommends that further work be undertaken to promote consistency in the interpretation and application of Article 13(1) b) including, but not limited to, allegations of domestic and family violence.

82. The Special Commission recommends that the Council on General Affairs and Policy authorize the establishment of a Working Group composed of judges, Central Authorities and cross-disciplinary experts to develop a Guide of Good Practice on the interpretation and application of Article 13(1) b), with a component to provide guidance specifically directed to judicial authorities, taking into account the Conclusions and Recommendations of past Special Commission meetings and Guides of Good Practice (HAGUE CONFERENCE ON PRIVATE INTERNATIONAL LAW, 2012a, p. 28-29)

In 2012, the Council on General Affairs and Policy of the Hague Conference did approve the establishment of the recommended Working Group (WG) (HAGUE CONFERENCE ON PRIVATE INTERNACIONAL LAW, 2012b, p. 6). The scope of the work was precisely the development of a Guide of Good Practice on the interpretation and application of Article 13(1) (b). ${ }^{29}$

As a soft-law mechanism (non-mandatory nature), the Guide can offer some level of clarification to the terms of the treaty, by presenting definitions, offering examples, and thus directing, at some extent, the interpretation of the exception terms, such as grave risk, physical harm, psychological harm or intolerable situation - an exercise important not only to the reduction of adjudication and compliance costs, but also to specification costs, both at the domestic (regarding implementation legislation and regulations) and at the international (long term discussions on amending the Hague Convention) levels.

Surely, its edition will not be able to totally avoid vagueness, interpretation difficulties or negative casuistry. Even a clear and efficiently drafted rule may be unable to avoid interpretation problems. However, the Guide appears to be in line with an efficient norm design that, in the long run, may even turn into a feasible rule-like text.

\section{CONCLUSIONS}

From the above analysis, we observe that the creation of the Hague Convention aimed at reaching a great membership on a sensitive matter: abduction of children and their restitution. The goal has been reached, if one considers the Hague Convention as one of the treaties under the Hague Conference that has, nowadays, the highest number of Contracting-States.

But our analysis spanned to the underlying cost structure of the treaty involving the so-called rules and standards debate. We exposed heightened specification costs, lower adjudication and 
compliance costs (especially due to the envisaged low frequency of cases) as a recommendation for the outcome of a standard, which turned to be the actual result, in a backsliding investigation.

Though many factors that affect the rules and standards categorization, we consider that the grave risk exception do encompass a standard. Its exact content cannot be fully known by adjudicators nor the public, ex ante. The negotiation processes revealed incessant attempts to reduce the vagueness of the provision. In conclusion, the adoption of the grave risk provision resembles an efficient legal design - or, at least, the most efficient legal design envisaged by the negotiators as possible to be achieved at this point in time.

The increase of cases and practice concerning the exception suggest that the grave risk provision could be improved. How to achieve it efficiently, in terms of legal design?

As the 2011-2012 Special Commission recommended, countries are now engaged on an exercise of elaborating a guide of good practices on the interpretation and application of Article 13 (1) (b) of the Hague Convention. Due to the higher number of Contracting States, the greater differences in cultures, and attached high specification costs, the Guide seems to be again an efficient tool. It may also reduce the costs of compliance and adjudication of the provision in the long run, paving the way for a rule-like text.

\section{A “EXCEÇÃO DE GRAVE RISCO”, EFICIÊNCIA E A CONVENÇÃO DE HAIA SOBRE SUBTRACุÃO INTERNACIONAL DE CRIANÇAS: UMA ABORDAGEM PELA ANÁLISE ECONÔMICA DO DIREITO}

\section{RESUMO}

Os Estados contratantes adotaram a Convenção de Haia sobre os Aspectos Civis do Sequestro Internacional de Crianças em 1980, após um extenso esforço de negociação. O texto final adicionou exceções ao objetivo primário de retorno imediato de crianças subtraídas indevidamente a um país diferente do que residia habitualmente. Entre elas, a exceção de grave risco trata de situações em que a criança, após seu retorno, pode sofrer danos físicos ou psicológicos ou ser colocada em uma situação intolerável. Postulamos neste artigo que a elaboração e evolução dessa exceção vêm ocorrendo de forma eficiente, em termos de design de normas jurídicas. Para fundamentar nossa hipótese, este artigo se baseia na metodologia da análise econômica do direito, mais especificamente, no debate entre regras e padrões. A pesquisa demonstra que os representantes dos Estados enfrentaram custos elevados de especificação e baixa frequência de casos (o que sugere a adoção de um padrão). Além disso, atualmente, a contínua presença de custos de especificação e a elaboração de um Guia de Boas Práticas relacionado à exceção parecem ser a melhor alternativa disponível para avançar a sua implementação. Portanto, tanto em sua origem quanto desenvolvimento, a exceção segue um modelo de eficiência em termos de design de normas jurídicas. 
Palavras-chave: Subtração internacional de crianças. Convenção de Haia. Exceção de grave risco. Análise Econômica do Direito. Regras e padrões.

\section{LA “EXCEPCIÓN DE GRAVE RIESGO”, EFICIENCIA Y EL CONVENIO DE LA HAYA SOBRE SUSTRACCIÓN INTERNACIONAL DE NIÑOS: UN ENFOQUE DEL ANÁLISIS ECONÓMICO DEL DERECHO}

\section{RESUMEN}

Los Estados Contratantes adoptaran el Convenio de La Haya sobre los Aspectos Civiles de la Sustracción Internacional de Niños en 1980, después de extenso esfuerzo de negociación. El texto final agregó excepciones al objetivo primario de restitución inmediata de niños indebidamente sustraídos a un país diverso del que él/ella residía con habitualidad. Entre ellas, la excepción de grave riesgo relacionase a situaciones en que el niño, en su regreso, puede sufrir daños físicos o psicológicos o ser puesto en situación intolerable. Postulamos en esta investigación que la elaboración y evolución de esta excepción vienen ocurriendo de manera eficiente, en términos del design de normas jurídicas. Para fundamentar nuestra hipótesis, este estudio se funda metodológicamente en el análisis económico del derecho (el debate entre reglas y estándares). La investigación demuestra que los representantes de los Estados enfrentaran costos elevados de especificación y baja frecuencia de casos (lo que sugiere la adopción de un estándar). Además, en la actualidad, la continua presencia de costos de especificación y la elaboración de una Guía de Buenas Prácticas relacionado a la excepción parecen ser la mejor alternativa disponible para el avance de su implementación. Por lo tanto, tanto en su origen cuanto desarrollo, la excepción sigue siendo un modelo de eficiencia en términos del design de normas jurídicas.

Palabras clave: Sustracción internacional de niños. Convenio de La Haya. Excepción de grave riesgo. Análisis económico del derecho. Reglas y estándares.

1 Hague Convention on the Civil Aspects of International Child Abduction, hereinafter named the Hague Convention.

2 The Convention does not encompass the criminal aspects of international child abduction. It regulates the conduct of wrongfully removals or retentions of children in a country different from the country of its habitual residence. The liability rests in the imposition on the abductor of the obligation to promptly return the child to its place of habitual residence. The abductor shall support the financial costs related to the return of the child.

3 Hague Convention, Article 1.

4 Although this exercise was initiated almost 5 years ago, the State-Parties were not, so far, able to reach consensus on its content. A final draft of the Guide is expected to be presented for the approval of State-Parties to the Hague Convention in October, 2017.

5 Treaties, on their classical form, are binding only to States. A treaty is applicable by a domestic law, generally, only indirectly, depending on the content of the treaty and its internalization to the domestic legislation of a State. 
6 The behavior of private parties - individuals under the jurisdiction of a State can be bound to treaties only indirectly, and only at some cases.

7 The commitment of an international child abduction will certainly be performed not by a member State, but by a private party - mostly parents.

8 Those joint efforts can be found on the ratification of any international treaty (at least in most countries).

9 Uruguay, Switzerland and the United States are examples of countries that have enacted domestic legislation to implement the Hague Convention.

10 "Hague Conference, Legal Kidnaping, Preliminary Document No. 1, Questionnaire and Report on International Child Abduction by one Parent (1978)", named the Dyer Report. The report has also profited from the work performed by the Council of Europe.

11 Other multilateral and bilateral initiatives, as well as efforts taken domestically by some States were also mentioned at the Dyer Report. Previous treaties adopted under the auspices of the Hague Conference, as the Convention of 5 October 1961 concerning the powers of authorities and the law applicable in respect of the protection of infants, among others, also have helped to reduce the costs of information.

12 One cannot deny that, in practical terms, there was, at some extent, an overlap between both initiatives. Overlaps, we believe, are a cost-increasing factor. On the other hand, the territorial potential of incidence of the Hague Convention is larger (when compared to the Council of Europe). This may explain, at least partially, why the latter organization did not consider the former effort an undue overlap.

13 As for December 1978 the Council of Europe was composed of 20 States (Denmark; France; Ireland; Italy; Luxembourg; Netherlands; Norway; Sweden; United Kingdom; Greece (withdrew from the Council membership during the Greek military junta of 1967-1974); Turkey; Iceland; Germany (the Federal Republic of Germany (West Germany) and the Saar Protectorate became associate members in 1950. The Federal Republic became a full member in 1951. The Saar acceded to the Federal Republic in 1956, and the states of the former East Germany became part of the Federal Republic upon reunification in 1990. East Germany had never been a member of the Council); Austria; Cyprus; Switzerland; Malta; Portugal (joined the Council in 22 September 1976); Spain (joined the Council in 24 November 1977); Liechtenstein (joined the Council in 23 November 1978).

14 The grave risk exception is not the only exception to the prompt return of internationally abducted children. Other exceptions are the settlement of the children to their new environment (after one year from the abduction and the commencement of the return proceedings); the objection of the child to its return, at cases where its age and level or maturity can make its position to be taken into consideration; the consent or acquiescence of the left behind parent to the reallocation of the child; the lack of actual exercise of its custody rights by the left behind parent at the moment of transfer or retention of the child; at least, the return of a child can be denied if this "would not be permitted by the fundamental principles of the requested State relating to the protection of the fundamental principles of the requested State relating to the protection of human rights and fundamental freedoms" (articles 12, 13 and 20 of the Hague Convention).

15 Hereinafter, Special Commission.

16 The conclusions from this meeting were published in June 1979 - "Conclusions Drawn from the Discussions of the Special Commission of March 1979 on Legal Kidnapping, The Permanent Bureau of the Hague Conference on Private International Law", Prel. Doc. No. 5, June 1979.

17 The United Nations Educational, Scientific and Cultural Organization (UNESCO) also proclaimed 1979 as the International Year of the Child.

18 The Chairman of this commission was Professor A.E. Anton (United Kingdom) and the Vice-Chairman was Dean Leal (Canada), who already had been Chairman and Vice-Chairman respectively of the Special Commission.

19 Argentina, Australia, Belgium, Canada, Czechoslovakia, Denmark, Finland, France, West Germany, Greece, Ireland, Italy, Japan, Luxemburg, Netherlands, Norway, Portugal, Spain, Sweden, Switzerland, United Kingdom, United States, Yugoslavia. A delegate from Turkey was present at the first meeting of the special Commission, in March 1979. 
20 Argentina, Australia, Austria, Belgium, Canada, Czechoslovakia, Denmark, the Arab Republic of Egypt, Finland, France, the Federal Republic of Germany, Greece, Ireland, Israel Italy, Japan, Yugoslavia, Luxembourg, the Netherlands, Norway, Portugal, Spain, Surinam, Sweden, Switzerland, Turkey, the United Kingdom, the United States of America and Venezuela.

21 Germany, Australia, Austria, Belgium, Canada, Denmark, Spain, United States, Finland, France, Greece, Ireland, Japan, Luxemburg, Norway, Netherlands, Portugal, United Kingdom, Sweden, Switzerland, Czechoslovakia, Venezuela and Yugoslavia. Delegates from Egypt, Israel and Italia, although they have taken an active role at the work of the First Commission (as the representatives of the Council of Europe, the International Social Service), they did not participate at the voting. Morocco, The Holy See and the URSS have sent observers.

22 We understand from our studies that there was, really, something very close to a belief, due to the fact that there were not readily available statistics on the transnational child abduction phenomena.

23 The decisions at the Commissions, as well as during the Fourteenth Session of the Hague Conference were taken by voting. It is worth mentioning that, nowadays, the voting system is not very common on the practice of international organizations, where the Security Council of the United Nations is one of the exceptions.

24 Among others, Australia, Ireland, Norway, Finland.

25 At the final version of the text, the Article 12(I)b was renumbered to Article 13(I)b.

26 See note above.

27 For Hague Convention statistics: <https://www.hcch.net/en/instruments/conventions/ publications $1 /$ ?did $=32 \&$ cid $=24>$.

28 As compared with the number of States that took part at the negotiation exercise of the Hague Convention (around 25), the actual number of States-Parties to this convention has increased not only in number, to encompass 97 countries, but also in cultural diversity and levels of development. We recall that during the negotiation phase only Turkey and Venezuela could be considered developing countries. Today one can say that the majority of the membership of the Hague Convention is composed by developing countries. It is important to mention that Muslin countries are still underrepresented at the Hague Convention.

29 Since then, the WG invited Contracting-States to take part on the discussions of the Working Group on Article 13(1) (b) of the 1980 Hague child Abduction Convention, in charge of elaborating of a Guide of Good Practices on the Interpretation and Application of Article 13(1)(b) of the 1980 Hague Child Abduction Convention. The Working Group has been convening since 2013. It intends to present the final draft of the Guide in 2019 for the consideration (and approval) of the HCCH's Member States.

\section{REFERENCES}

BAIRD, Douglas G.; WEISBERG, Robert. Rules, Standards, and the Battle of the Forms: a Reassessment of §2-207. Virginia Law Review, v. 68, p. 1217-1262, 1982.

BEAUMONT, Paul R.; McELEAVY, Peter E. The Hague Convention on International Child Abduction. New York: OUP, 1999.

BODENHEIMER, Brigitte M. The hague draft convention on international child abduction. Family Law Quarterly, v. 14, n. 2, p. 99-120, 1980.

DIVER, Colin S. The Optimal Precision of Administrative Rules. 93 Yale L. J., v. 93, p. 65-109, 1983.

DOWNS, George W.; ROCKE, David M. Optimal Imperfection? Domestic Uncertainty and Institutions in International Relations. Princeton, N.J.: Princeton University Press, 1995. 
DUNOFF, J. L.; TRACHTMAN, J. P. Economic Analysis of International Law. The Yale Journal of International Law, v. 24, n. 1, p. 1-59, 1999.

EHLRICH, Isaac; POSNER, Richard A. An Economic Analysis of Legal Rulemaking. The Journal of Legal Studies, v. 3, n. 1, p. 257-286, jan. 1974.

GOLDSMITH, J. L.; POSNER, E. The limits of International Law. Oxford: OUP, 2005.

GUZMAN, A. T. How international law works. Oxford: OUP, 2008.

HAGUE CONFERENCE ON PRIVATE INTERNATIONAL LAW. Actes and document de la Quatorzième session, au 6 au 25 Octobre 1980: enlèvement d'enfants. The Hague: Imprimerie National of the Hague, 1982. Tome III. p. 1-482.

HAGUE CONFERENCE ON INTERNATIONAL PRIVATE LAW. Overall Conclusions of the Special Commission of October 1989. 1989. Available at: < https://assets. hcch.net/upload/abdrpt89e.pdf $\geq$. Access in: 8 Oct. 2018.

HAGUE CONFERENCE ON PRIVATE INTERNATIONAL LAW, Report of the second Special Commission meeting, 1993. 1993. Available at: <https://assets.hcch.net/ upload/abdrpt93e.pdf $\geq$. Access in: 8 Oct. 2018.

HAGUE CONFERENCE ON PRIVATE INTERNATIONAL LAW. Consultations on the desirability and feasibility of a Protocol to the Hague Convention of 25 October 1980 on the Civil Aspects of International Child Abduction: a preliminary report. Prel. Doc. No 7 of May 2011a. Available at: <https://assests.hcch.net/upload/wop/abduct2011pd07e.pdf $\geq$. Access in: 8 Oct. 2018.

HAGUE CONFERENCE ON PRIVATE INTERNATIONAL LAW. Guide to Parte II of the Sixth Meeting of the Special Commission and Consideration of the desirability and feasibility of further work in connection with the 1980 and 1996 Convention (Annex). Prel. Doc. No 13 of December 2011b. Available at: <https://assets.hcch.net/ upload/wop/abduct2012pd13_e.pdf $\geq$ Access in: 8 Oct. 2018.

HAGUE CONFERENCE ON PRIVATE INTERNATIONAL LAW. Conclusions and Recommendations of Part I and Part II of the Special Commission on the practical operation of the 1980 Child Abduction Convention and the 1996 Child Protection Convention, and a Report of Part II of the meeting, 2012. 2012a. Available at: <https://assets.hcch.net/upload/wop/concl28-34sc6_en.pdf.> Access in: 8 Oct. 2018.

HAGUE CONFERENCE ON PRIVATE INTERNACIONAL LAW. Conclusion and Recommendations adopted by the Council on General Affairs and Policy of the Conference, 2012. 2012b. Available at: < https://www.hcch.net/en/governance/council-on-general-affairs/archive $\geq$. Access in: 8 Oct. 2018. 
HAGUE CONFERENCE ON PRIVATE INTERNATIONAL LAW. Child Abduction Section. 2016. Available at: <https://www.hcch.net/en/instruments/conventions/specialised-sections/child-abduction>. Access in: 8 Oct. 2018.

HAGUE CONFERENCE ON PRIVATE INTERNATIONAL LAW. About HCCH. 2017. Available at: <https://www.hcch.net/en/about>. Access in: 8 Oct. 2018.

KAPLOW, Louis. Rules versus Standards: An Economic Analysis. Duke Law Journal, v. 42, p. 557-629, 1992.

KAPLOW, Louis. General Characteristics of Rules. Encyclopedia of Law and Economics, v. 5, p. 502-528, 1999. Available at: <http://encyclo.findlaw.com/9000book. pdf $>$. Access in: 8 Oct. 2018.

KENNEDY, Duncan. Form and Substance in Private Law Adjudication. Harvard Law Review, v. 89, p. 1685-1778, 1976.

MICHAELS, Ralf. Economics of Law as Choice of law. Law and Contemporary Problems, v. 71, p. 73-106, 2008. Available at: <http://scholarship.law.duke.edu/lcp/ vol71/iss3/4>. Access in: 8 Oct. 2018.

O'HARA, Erin Ann; RIBSTEIN, Larry E. Conflict of Laws and Choice of Law. Encyclopedia of Law and Economics, v. 5, p. 631-660 1999. Available at: <http:// encyclo.findlaw.com/9600book.pdf>. Access in: 8 Oct. 2018.

PÉREZ-VERA, Elisa. Explanatory Report on the Hague Child Abduction Convention. The Hague: The Hague Conference of International Private Law Publications, 1982. Available at: <https://assets.hcch.net/upload/expl28.pdf $>$. Access in: 8 Oct. 2018.

POSNER, Richard A. Economic analysis of law. New York: Aspen Publisher, 2007. RÜHL, Giesela. Methods and approaches in choice of law: an economic perspective. Berkley Journal of International Law, v. 24, n. 3, p. 801-841, 2006.

SCHÄFER, Hans-Bernd. Legal Rules and Standards. German Working Papers in Law and Economics, v. 2, p. 1-7, 2002.

SHAPIRA, Amos. Private international law: aspects of child custody and child kidnapping cases. Recueil des Cours de l'Académie de Droit International de la Haye, v. 214, p. 127-250, 1989.

SCHUZ, Rhona. Disparity and the Quest for Uniformity in Implementing the Hague Abduction Convention. Journal of Comparative Law, v. 9, n. 1, p. 3-48, 2014.

SILBERMAN, Linda J. Co-Operative Efforts in Private International Law on Behalf of Children: The Hague Children's Conventions. Recueil des Cours de l'Académie de Droit International de la Haye, v. 323, p. 265-477, 2006. 
SUNSTEIN, Cass R. Problems with Rules. California Law Review, v. 83, n. 4, p. 953 1026, jul. 1995.

THE INTERNATIONAL SOCIAL SERVICE. Mission. 2016. Available in <http:// www.iss-ssi.org/index.php/en/home/mission >. Access in: 8 Oct. 2018.

TRACHTMAN, Joel P. The Future of International Law. New York: Cambridge University Press, 2013.

WEINER, Merle H. International Child Abduction and the escape from domestic violence. Fordham L. Rev, v. 69, n. 2, p. 593-706, 2000. 